\title{
Influence of Age, Estrogen receptor (ER),Progesterone receptor (PR) and Epidermal growth factor -2 (HER-2) in Breast Carcinoma Patient in correlation with Radionuclide Bone Scan - Single Institute Based Experience
}

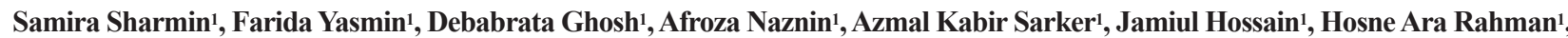 \\ Md. Monir Uddin², Syed Muhammad Baqui Billah ${ }^{3}$ \\ 'Institute of Nuclear Medicine and Allied Sciences, Sir SalimullahMedical College Campus, Mitford, Dhaka \\ ${ }^{2}$ Cumilla Medical College \\ ${ }^{3}$ Sulaiman Al Rajhi University, KSA
}

Correspondence Address: Dr. Samira Sharmin, Senior Medical Officer, Institute of Nuclear Medicine \&Allied Sciences,SSMCH Campus, Mitford, Dhaka.samira958@gmail.com

\begin{abstract}
Background: Breast carcinoma is a common type of malignancy in women worldwide. Radionuclide bone scintigraphy is recognized choice of investigation for the detection of bone metastases both in asymptomatic and symptomatic patients. Biomarkers like Estrogen Receptor (ER), Progesterone Receptor (PR), Human Epidermal growth factor -2 (HER-2) also play important role in the management and prognosis of breast cancer. The study was aimed to find out the relationship between the MDP bone scan findingsand hormone receptor and HER-2 status of breast carcinoma patients referred to the Institute of Nuclear Medicine and Allied Sciences (INMAS), Mitford, Dhaka.
\end{abstract}

Patients and Methods: This cross sectional study was conducted among 301 breast carcinoma patients between January 2018 and December 2019. Planar bone scan and SPECT (if needed) was done to all the patients after intravenous injection of $99 \mathrm{mTc}-\mathrm{MDP}$. Receptor status (ER, PR and HER-2) were documented from the patient's medical records. Breast tumors were classified as (a) Triple positiveHER2-, ER-, and PR-positive) (b) Triple negative- HER2-, ER-, and PR-negative (c) Hormonereceptor (HR) positive $(\mathrm{ER}+/ \mathrm{PR}+)$ with HER-2 negative and d) HR negative (ER-/PR-) with HER-2 positive.Patients were broadly grouped according to age as A. less than 50 years $(n=59)$ and B. more than $50(n=260)$ years.

Results: The mean age of the patients enrolled for this study was $59.02 \pm 9.3$ with range of 32 to 81 years. Out of the 301 patients, positive bone scans were found in $105(34.8 \%)$ and negative bone scan were found $196(66.2 \%)$. Patients of group A (<50years) with triple negative and HR+/HER-status had no bone or bone with visceral metastases. Triple positive subtype had 2 bone metastases, and HR-/HER-2+ subtype had 2 bone metastases and 1 had bone with visceral metastases.

Group B (> 50years) patients having HR+/HER2- receptor status showed $16 \%$ solitary metastases, $53.2 \%$ multiple metastases, $33.3 \%$ extensive bony metastases, $13.6 \%$ bone with visceral metastases.
Triple negative subtype showed $36.0 \%$ solitary metastases, $19.1 \%$ bone with visceral metastases. Triple positive subtype group had $40.0 \%$ solitary metastases, $34.0 \%$ multiple metastases, $66.7 \%$ extensive bony metastases, and $13.6 \%$ bone with visceral metastases. HR-/HER-2+ subtype group had 8\% solitary metastases, $12.8 \%$ multiple metastases, and $18.2 \%$ bone metastases with visceral involvement

Overall relationship between bone scan and hormone receptor subtype, showed that most of the patients had HR+/ HER-2-(35.2\%) subtype and $25.6 \%$ patient had triple positive, $23.3 \%$ patient had triple negative and $15.9 \%$ patient had HR-/HER-2 - receptor subtype.

This study showed the visceral involvement with bone metastases (13\% in HR+/HER-2- $52.2 \%$ in triple negative, $13 \%$ in triple positive, $21.7 \%$ in HR-/HER-2+subtype). Highest bone only metastases (35) in triple positive and HR+/HER-2-(31) subtype. Most of the patiens who had bone metastases with visceral involvement belong to triple negative (52.2\%) and HER-2 subtypes -HR-/HER-2+ (21.7\%). The result was significant $(\mathrm{P}<0.001)$.

Conclusion: It is observed from this study that triple positive and HR+/HER-2- were more likely to develop bone metastases than triple negative and HR-/HER-2-. Patients with bone scan negative and HR-/HER-2- or triple negative receptor status most likely develop visceral metastases

Key words: Bone scan, Estrogen receptor, Progesterone receptor, Human Epidermal Growth factor-2, visceral metastases.

Bangladesh J. Nucl. Med. Vol. 22 No. 2 July 2019

Doi: https://doi.org/10.3329/bjnm.v22i2.51761

\section{INTRODUCTION}

Metastatic involvement of bone is very common in breast carcinoma (1). Radionuclide bone scan is a 
well-accepted method for detection of skeletal metastases (2).Among the different types of biomarkers Estrogen receptor (ER), Progesterone receptor (PR) and Human epidermal growth factor receptor 2 (HER-2) play important roles in the treatment plan and prediction of metastatic sites both in symptomatic and asymptomatic breast carcinoma patients (1). This study was designed at INMAS, Mitford, Dhaka to see how age, hormone receptor status and genetics influence breast cancer metastases to bones in relation to 99mTc-MDP bone scintigraphy findings in different age group of patients.

\section{PATIENTS AND METHODS}

This cross sectional study was done in the Institute of Nuclear Medicine and Allied Sciences (INMAS), Mitford between January 2018 to December 2019. Total 301 breast carcinoma patients were enrolled in this study. Anterior and posterior planar images were acquired after intravenous injection of 99mTc-MDP with Siemens dual head gamma camera. Patient's data were documented for the Immunocyto-histochemistry report of hormone receptor status and HER-2 status. Paraffin Sections of the formalin fixed tissue were stained for estrogen receptor using DAKO clone ID5, progesterone receptor using DAKO clone PgR636 and cerb2 using DAKOA0485. The detection system used was DAKO envision. For ER and PR the staining was considered positive when at least $1 \%$ of tumor nuclei expressed the proteins, HER-2 expression was classified as positive $(3+)$, when at least $10 \%$ positive tumor cells show strong complete membrane staining and considered as negative (score $0+$ or $1+$ ) with less than that.

\section{RESULTS}

Most of the patients enrolled were in age group 50-60 years with mean age 59.02 \pm 9.3 years and range from 32 to 81 . Sternum was most affected site in case of solitary metastatic lesion (38\%) and pelvis was mostly affected site in multiple metastatic (19\%) lesion. Among the breast carcinoma patients positive bone scan was $34.8 \%$ and negative bone scan was $66.2 \%$. The characteristics of the study subjects are given in Table 1.
Table 1: Characteristic of study subject:

\begin{tabular}{lll}
\hline Study subjects & Characteristics & P value \\
\hline Total number & 301 & \\
Mean age with range & $59.02 \pm 9.36(32 \sim 81)$ & \\
Mean age with range in Group A & $43.27 \pm 4.38(32 \sim 49)$ & \\
Mean age with range in Group B & $61.50 \pm 7.28(50 \sim 81)$ & \\
Positive bone scan & $105(35 \%)$ & \\
Solitary & $26(25 \%)$ & 0.09 \\
Multiple & $49(47 \%)$ & \\
Extensive & $7(6 \%)$ & \\
Positive bone scan with visceral mets & $23(22 \%)$ \\
Negative bone scan & $196(66 \%)$ \\
Highest solitary metastatic lesion & $10(38 \%)$ \\
site sternum & \\
Highest multiple metastatic lesion & $20(18 \%)$ \\
site pelvis & \\
\hline
\end{tabular}

The relationship with age and hormone receptor was not significant $(\mathrm{P}>0.05)$ and the status is shown in Table 2.

Table 2: Relationship between age and the hormone receptor status

\begin{tabular}{llll}
\hline $\begin{array}{l}\text { Hormone } \\
\text { receptor }\end{array}$ & $\begin{array}{l}\text { Patient's } \\
\text { Number } \\
\mathbf{n}(\%)\end{array}$ & $\begin{array}{l}\text { Age } \\
\text { (Mean } \pm \text { Standerd } \\
\text { deviation) }\end{array}$ & P value \\
\hline HR+/HER-2- & $106(35.5)$ & $57.94 \pm 9.2$ & \\
Triple negative & $70(23.3)$ & $60.76 \pm 8.8$ & \\
Triple positive & $77(25.6)$ & $59.40 \pm 10.1$ & 0.23 \\
HR-/HER-2+ & $48(15.9)$ & $58.25 \pm 8.7$ & \\
Total & $\mathbf{3 0 1 ( 1 0 0 )}$ & $\mathbf{5 9 . 0 2 \pm 9 . 3}$ & \\
\hline
\end{tabular}

Group A had $13.7 \%$ patients with mean age $43.27 \pm 4.38$ years. In this group all patients had negative bone scan in triple negative and HR+/HER2- subtype. The relationship with group $\mathrm{A}$ and hormone receptor are shown in Table 3.

Table 3: The relationship with group A ( $<50 \mathrm{yrs})$ with hormone receptor

\begin{tabular}{|c|c|c|c|c|c|c|}
\hline \multirow{3}{*}{$\begin{array}{l}\text { Hormone } \\
\text { receptor }\end{array}$} & \multicolumn{5}{|c|}{ Bone scan status } & \multirow{3}{*}{$\begin{array}{ll} & \text { Total } \\
- & \mathbf{n}(\%) \\
& \\
\text { n } & \\
& \\
\end{array}$} \\
\hline & Negative & Solitary & Multiple & Extensive & Positive & \\
\hline & $\begin{array}{c}\text { bone scan } \\
(\mathbf{n} / \%)\end{array}$ & mets (n/\%) & mets $(\mathrm{n} / \%)$ & mets $(n / \%)$ & $\begin{array}{l}\text { bone scan } \\
\text { with organ } \\
\text { involvement } \\
(\mathbf{n} / \%)\end{array}$ & \\
\hline HR+/HER-2- & $19(52.3)$ & 0 & 0 & 0 & 0 & $19(46.3)$ \\
\hline Triple negative & $7(19.4)$ & 0 & 0 & 0 & 0 & $7(17.1)$ \\
\hline Triple positive & $7(19.4)$ & $1(100)$ & 0 & $1(100)$ & 0 & $9(22)$ \\
\hline HR-/HER-2+ & $3(8.3)$ & 0 & $2(100)$ & 0 & $1(100)$ & $6(14.6)$ \\
\hline Total & $36(100)$ & $1(100)$ & $2(100)$ & $1(100)$ & $1(100)$ & $41(100)$ \\
\hline
\end{tabular}


About $86.3 \%$ patients belonged to the group B with mean age $61.50 \pm 7.28$ years. Table 4 shows the results.

Table 4: Association between the bone scan and the hormone receptor status in group $B$

\begin{tabular}{|c|c|c|c|c|c|c|}
\hline \multirow{2}{*}{$\begin{array}{l}\text { Hormone } \\
\text { receptor }\end{array}$} & \multicolumn{5}{|c|}{ Bone scan result } & \multirow{2}{*}{$\begin{array}{r}\text { Total } \\
-\mathrm{n}(\%)\end{array}$} \\
\hline & $\begin{array}{l}\text { Negative } \\
\text { bone scan } \\
\text { n( } \%)\end{array}$ & $\begin{array}{l}\text { Solitary } \\
\mathrm{n}(\%)\end{array}$ & $\begin{array}{l}\text { Multiple } \\
\mathrm{n}(\%)\end{array}$ & $\begin{array}{l}\text { Extensive } \\
n(\%)\end{array}$ & $\begin{array}{l}\text { Positive } \\
\text { bone scan } \\
\text { with visceral } \\
\text { involvement } \\
\mathrm{n}(\%)\end{array}$ & \\
\hline HR+/HER-2- & $53(33.1)$ & $4(16)$ & $25(53.2)$ & $2(33.3)$ & $3(13.6)$ & $87(33.5)$ \\
\hline Triple negative & $42(26.3)$ & $9(36)$ & $0(0)$ & $0(0)$ & $12(54.5)$ & $63(24.2)$ \\
\hline Triple positive & $35(21.9)$ & $10(40)$ & $16(34)$ & $4(66.7)$ & $3(13.6)$ & $68(26.2)$ \\
\hline HR-/HER-2+ & $30(18.8)$ & $2(8)$ & $6(12.8)$ & $0(0)$ & $4(18.2)$ & $42(16.2)$ \\
\hline Total & $160(100)$ & $25(100)$ & $47(100)$ & $6(100)$ & $22(100)$ & $260(100)$ \\
\hline
\end{tabular}

The result was significant $(\mathrm{P}<0.05)$. Distribution of hormone receptor subtype among the two age group (group A \& B) showed below (Figure-1).

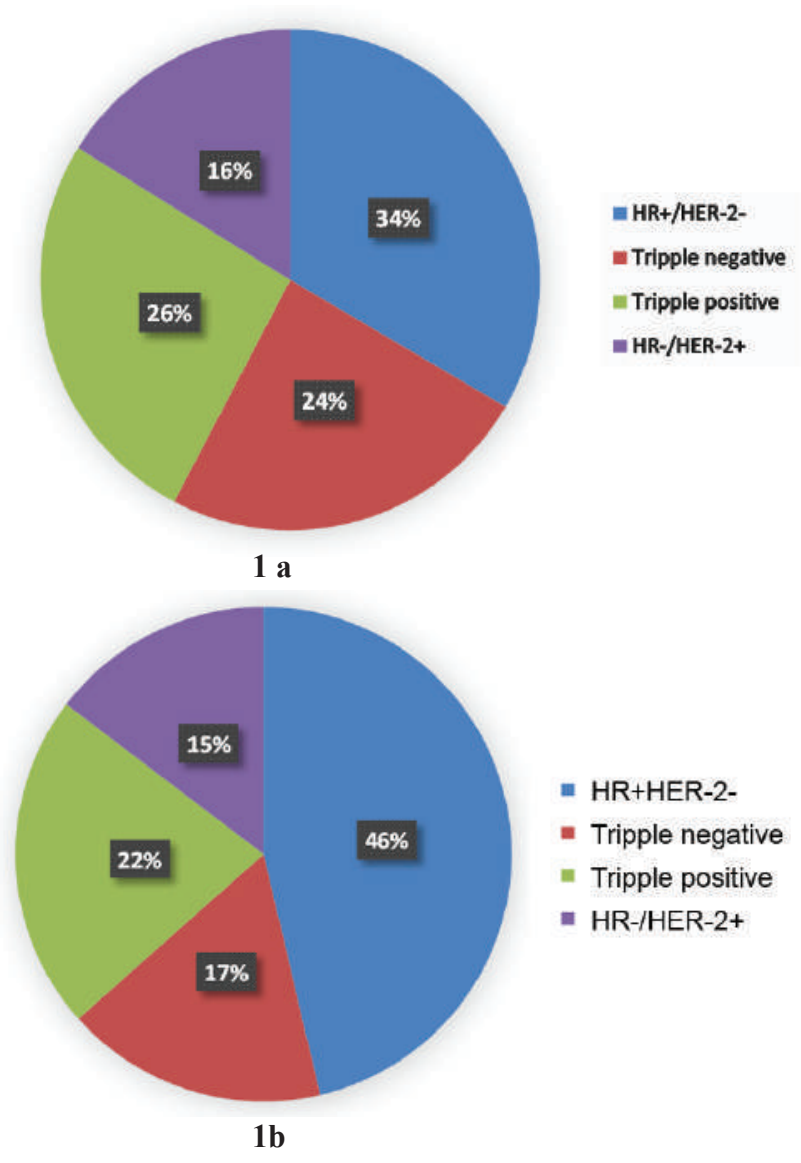

Figure-2 : (a) Distribution of hormone receptor subtype among the study subjects in Group A

b) Distribution of hormone receptor subtype among the study subjects in Group B
The overall relationship between bone scan and hormone receptor subtypes showed that total $35.2 \%$ patient in HR+/HER-2- subtype, among them 36.7\% negative bone scan, $15.4 \%$ solitary metastases, $51 \%$ multiple metastases, $28.6 \%$ had extensive bone metastases, bone metastases with visceral involvement had $13 \%$. Triple negative subtype showed $25 \%$ negative bone scan, $34.6 \%$ solitary metastases, no one had multiple or extensive bony metastases, and $52.2 \%$ had bone metastases with visceral involvement. The association between the hormone receptor and HER-2 status is given in Table- 5 .

\begin{tabular}{cccccccc}
\hline $\begin{array}{c}\text { Hormone } \\
\text { Receptor with } \\
\text { HER-2 }\end{array}$ & \multicolumn{5}{c}{ Bone scan result } & $\begin{array}{c}\text { Total } \\
(\mathbf{n} / \%)\end{array}$ & $\begin{array}{c}\text { P } \\
\text { value }\end{array}$ \\
\cline { 2 - 6 } & $\begin{array}{c}\text { Negative } \\
(\mathbf{n} / \%)\end{array}$ & $\begin{array}{c}\text { Solitary } \\
(\mathbf{n} / \%)\end{array}$ & $\begin{array}{c}\text { Multiple Extensive Positive bone } \\
(\mathbf{n} / \%)\end{array}$ & $\begin{array}{c}(\mathbf{n} / \%) \\
\text { scan with } \\
\text { visceral mets } \\
(\mathbf{n} / \%)\end{array}$ & \\
\hline HR+/HER-2- & $72(36.7)$ & $4(15.4)$ & $25(51.0)$ & $2(28.6)$ & $3(13.0)$ & $106(35.2)$ \\
Triple negative & $49(25)$ & $9(34.6)$ & 0 & 0 & $12(52.2)$ & $70(23.3)$ \\
Triple positive & $42(21.4)$ & $11(42.3)$ & $16(32.7)$ & $5(71.4)$ & $3(13.0)$ & $77(25.6)<0.001$ \\
HR-/HER-2+ & $33(16.8)$ & $2(7.7)$ & $8(16.3)$ & 0 & $5(21.7)$ & $48(15.9)$ \\
Total & $\mathbf{1 9 6}$ & $\mathbf{2 6}$ & $\mathbf{4 9}$ & $\mathbf{7}$ & $\mathbf{2 3}$ & $\mathbf{3 0 1}$ \\
\hline
\end{tabular}

Triple positive subtype showed $21.4 \%$ negative bone scan, $42.3 \%$ solitary metastases, $32.7 \%$ multiple metastases, $6.5 \%$ had extensive bone metastases and $71.4 \%$ had bone with visceral metastases. HR-/HER-2+ subtype showed $16.8 \%$ negative bone scan, $7.7 \%$ solitary metastases, $16.3 \%$ multiple metastases, no one had extensive bone metastatic lesions, and $21.7 \%$ had bone with visceral metastases.

\section{DISCUSSION}

Breast cancer commonly metastasize to the bone and the hormonal receptor status can predict the metastatic site (3). Most of the patients in the study was in between 50-60 years and least patient was in age between 30-40 years and 70-80 years which was consistent with study conducted by Neesa et al. (2018). They showed the similar findings, age range of their study subject was 32 to 81 years and least patient was in age group $<40$ years and $>80$ years (4). Another study conducted by Lee et al. (2011) also found the similar results (5).

Regarding the age distribution according to the hormone receptor subtype, this study showed that 106 
patient in subtype HR+/HER2- with mean age $57.95 \pm 9.2,70$ patients in triple negative subtype with mean age $60.76 \pm 8.8,77$ in triple positive subtype with mean age $59.4 \pm 10.1$, 48 patients in HR-/HER-2+ subtype with mean age $58.25 \pm 8.7$ years. Similar results were found in a study conducted by Uden et al., who showed that 340 patient in HR+/HER-2-subtype with median age 61,125 patient in triple negative subtype with median age 62 years, 131 patient in triple positive with median age 60 years, 148 had HR-/HER-2+ receptor status with median age 57.5 (6).

The distribution of the bone metastases in this study showed multiple metastases were in the pelvis (18\%) and thenribs (17\%). In case of solitary metastases most of the metastatic lesions were found in the sternum (38\%). The pelvis as well as the ribs both showed the similar percentage of solitary metastatic lesions (19\%). This findings were consistent with the study conducted by Koizumi et al. (2003). They found most of the metastatic lesions in pelvis (14.6\%) in case of multiple metastases and $33.9 \%$ in the sternum in case of solitary metastatic lesion (2).

This study showed that in group A, no one had positive bone scan in triple negative and HR+/HER-2- subtypes. Whereas, the patients of triple positive subtype had both solitary and extensive bone metastases. HR-/HER-2+ subtype showed that (3) $8.3 \%$ had negative bone scan, 2 had multiple metastases, and 1 had positive bone scan with visceral metastases.

In the group B, we found that in HR+/HER-2- receptor status, $53.2 \%$ had multiple metastases. In triple negative group most of the patient $(54.5 \%)$ had bone with visceral metastases.

In comparison between group A (age $<50$ years) and group B (age $>50$ years), triple negative subtype had least bone metastases. This study also showed that the patients with triple negative receptor status usually present with bone metastases along with visceral involvement in group B (54.5\%). Among all the patients, HR+/HER-2-subtype showed highest bone only multiple metastases $(53.2 \%)$ which is consistent with the study conducted by Uden et al. (2019). This author showed that triple negative hormone status showed least bone metastases(41.6\%) but present with visceral metastases (74.4\% liver, lung, brain) whereas HR+/HER-2- subtype showed highest bone only metastases $(71.5 \%)$ (6) that goes with the findings of Xiao et al. (2018) who found $8 \%$ bone metastases in triple negative breast carcinoma patients (7).

Overall association between bone scan and the hormone receptor subtype in this study showed that most of the patients had HR+/HER-2-(35.2\%) status and triple positive subtype was $25.6 \%$, triple negative was $23.3 \%$, $15.9 \%$ patients had HR-/HER-2- subtype. A study conducted by Parkes et al.(2018) showed that majority of the patients were HR+/HER2- (78\%), triple positive was $11 \%$, triple negative was $7 \%$ and $3 \%$ patients was HR-/HER-2 + positive (8). Another study conducted by Uden et al. (2019) found the similar result. They showed that $45.7 \%$ was HR+/HER2-, $17.6 \%$ was $\mathrm{HR}+/ \mathrm{HER} 2+$, $16.8 \%$ was HR-/HER2- and $19.9 \%$ was HR-/HER2subtype (6).

This study also revealed that the association between bone scan and HR/HER-2 subtype showed that most of patients had bone metastases in triple positive (32) and HR+/HER-2- subtype (31). This findings was consistent with the study Gong et al.(2017) showed that majority bone metastases (79.7\%) in subtype $\mathrm{HR}+1$ HER-2- and then triple positive subtype (68.7\%)(9). Another study conducted by Lee et al. (2011) showed the similar findings that bone only metastases were common in the $\mathrm{HR}+(85 \%)$ group than in the other subtypes $(8.2 \%$ for HER-2+ and $6.8 \%$ for triple negative subtype (5).

Bone metastases was common in all subtypes in this study e.g. $15.4 \%$ in HR+/HER-2-, 34.6\% in triple negative group, $42.3 \%$ in triple positive group, $7.7 \%$ in HR-/HER-2 +.

A study conducted by Gong et al. (2017) found the similar findings that all subtype had bone only metastases e.g. HR+/HER-2- had 79.7\%, triple negative had $43 \%$,triple positive had $61 \%$ and HR-/HER-2+ had $35.8 \%(9)$.

The present study showedthat inall subtype had bone metastases with visceral involvement found in triple negative group (52.2\%) thenHR-/HER2+ subtype (21.7 
$\%$ ). This findings was consistent with the study conducted by Uden et al. (2019). They showed that visceral metastases significantly morecommon (40.8\%) in triple negative group and HR-/HER-2+ subtype (41.2\%) (6). Another study conducted by Xiao et al. (2018) also showed that HER2+ subtypes (HR+/HER2+ and $\mathrm{HR}-/ \mathrm{HER} 2+$ ) were significantly associated with higher rates of visceral metastases (7).

\section{CONCLUSION}

The study reveals that HR+/HER-2 - and triple positive group weremostly metastasize to the bone. Triple negative and HR-/HER-2+receptor status can present with bone with visceral metastases.

\section{REFERENCES}

1. Soni A, Ren Z, Hameed O, Chanda D, Morgan CJ, Siegal GP, Wei S. Breast cancer subtypes predispose the site of distant metastases. American journal of clinical pathology. 2015 Apr $1 ; 143(4): 471-8$.

2. Koizumi M, Yoshimoto M, Kasumi F, Ogata E. Comparison between solitary and multiple skeletal metastatic lesions of breast cancer patients. Annals of oncology. 2003 Aug $1 ; 14(8): 1234-40$.

3. Winczura P, Sosińska-Mielcarek K, Duchnowska R, Badzio A, Lakomy J, Majewska H, Pęksa R, Pieczyńska B, Radecka B, Dębska-Szmich S, Adamowicz K. Immunohistochemical predictors of bone metastases in breast cancer patients. Pathology \& Oncology Research. 2015 Sep; 21(4):1229-36.

4. Nessa A, Hussain T, Alam SM, Faruk I, Jahan I. Age distribution pattern of female breast cancer patients in Bangladesh-developing early and presenting late. International Surgery Journal. 2018 Jan 25;5(2):379-82.

5. Lee SJ, Park S, Ahn HK, Yi JH, Cho EY, Sun JM, Lee JE, Nam SJ, Yang JH, Park YH, Ahn JS. Implications of bone-only metastases in breast cancer: favorable preference with excellent outcomes of hormone receptor positive breast cancer. Cancer research and treatment: official journal of Korean Cancer Association. 2011 Jun;43(2):89.

6. Van Uden DJ, Van Maaren MC, Strobbe LJ, Bult P, Van Der Hoeven JJ, Siesling S, De Wilt JH, Blanken-Peeters CF. Metastatic behavior and overall survival according to breast cancer subtypes in stage IV inflammatory breast cancer. Breast cancer research. $2019 \mathrm{Dec} ; 21(1): 1-9$.

7. Xiao W, Zheng S, Yang A, Zhang X, Zou Y, Tang H, Xie X. Breast cancer subtypes and the risk of distant metastasis at initial diagnosis: a population-based study. Cancer management and research. 2018; 10:5329.

8. Parkes AM, Clifton K, Al Awadhi A, Oke O, Warneke CL, Litton JK, Hortobagyi GN. Characterization of bone only metastasis (BOM) patients (pts) with respect to tumor subtypes (TS).Journal of Clinical Onchology.2017; 15:1072

9. Gong Y, Liu YR, Ji P, Hu X, Shao ZM. Impact of molecular subtypes on metastatic breast cancer patients: a SEER population-based study. Scientific reports. 2017 Mar 27;7(1):1 